\title{
RITUAL IN JAPANESE COMPANY: THE CASE OF ASAKAI
}

\author{
Radita Astriyuni \\ The London School of Public Relation \\ radita.astriyuni92@gmail.com
}

\begin{abstract}
Poor communication is a serious problem for an organization. Based on its culture, each company has to find a strategy to improve the quality of organizational communication. This research sought to investigate how a Japanese company with their culture strived to resolve and prevent poor communication problem in the organization as represented in aritual, called ASAKAI.The research also focuses on how the local employees react to this ritual which is different than that of Indonesian companies. Qualitative data were collected by observation of practice and face to face interview that were conducted in PT. TMMIN, particularly Engineering Division. The findings revealed that ASAKAI has animportant role to improve and maintain the quality of organizational communication. The local employees also assumeand believe that ASAKAI is a good activity and no employees stand against it. The perceived conflict occured not because of the cultural difference, but because of the person whom are leading the ASAKAI.
\end{abstract}

Keywords: Organizational communication, Organizational culture, Intercultural conflict

\section{INTRODUCTION}

The English word organization derived from Greek word organon, that means 'tool' or 'instrument'. Communication is the activity in order to achieve organizational goals that created and sustained by coordinating mechanism among members of organization. Therefore, communication and organization are highly intercorrelated (Modaff, Dewine, \& Buttler, 2007). To many organizations, communication is the most essential component to their prosper (Boer, 2018). Not only for organization, but also in everyday human life. Gamble and Gamble (2002, p. 4) has stated that: "communication is the core of our humanness", and that "how we communicate with each other shapes our lives and our world". Communicative skills help people to reach out to one another or to confront occurrence that challenge our flexibility, integrity, expressiveness and critical thinking skills (Gamble \& Gamble, 2002).

Communication has a big role to contribute towards the organizational success. It is necessary to find the strategy in order to improve the quality of organizational communication. According to Elashmawi and Harris (1993), communication is main component in order to understanding how organization should, even must, behave in organizations if they are to advance their careers. Back then, during management meeting, the Director at my previous work place was going mad to all managers and stated this statement: "indeed, we have many problems, the biggest problem is not the quality of our products, but the quality of our communication. it seems like in XYZ, communication is very very expensive". Indeed, poor communication is a serious problem. But the author has never thought that communication can be costly. Whereas the quality of products, goods, customers satisfaction are depends on how good the quality of organizational communication.

Communication and organization are intimately interrelated. Likewise organization and culture.Schein (2010) defined that the culture as a guide to force the behavior of members of the group through the shared norms that are held in that group (p. 14). It means, organizational culture is the concept to control the way how the people within organization should behave. Currently the author is working at PT. Toyota Motor Manufacturing Indonesia (TMMIN). This company is Japanese multinational automotive manufacturer that headquartered in Japan. TMMIN is one of the largest Japanese Company in Indonesia. In order to maintain the internal communication, by following its culture, there is a ritual that we have to do every morning called, ASAKAI. Generally, the ritual of ASAKAI will take for about $20-30$ minutes to do, and will be led by each Department Head or that we used to call manager. ASAKAI is not only occur at my current workplace, but also occur at almost 
all Japanese Company. As observer, the author is considering this culture has function as their strategy to improve and maintain the quality of communication within organization.

This research focuses on how Japanese company with their culture strived to resolve and prevent poor communication in the organization as represented in ASAKAI, and how the local employees react to this ritual which is different than that of Indonesian companies. The scope of this research is limited only to ASAKAI at my workplace, TMMIN, particularly Engineering Managemnt Division, and focuses on the ordinary employees'response (not management level).

\section{Organizational Culture}

The organizational culture is the set of artifacts, values, and assumptions that emerge from the interactions of organizational members. In some cases the culture is hard to describe, but as a member of the organization we will know and realize what is the habit or value like within our organization. It means that the culture voiced how the construct plays out in the workplace, and how the organizational culture influences the attitude and behavior of employees (Keyton, 2011, p. 1).

Deal and Kennedy (as cited in Modaff et al, 2007, p. 92) mentioned that high perfoming organizations have strong cultures, and the following are the four key components to a strong culture: (1) Values - The fundamental character of the organization and provide concrete guidelines to members for achieving success; (2) Heroes - The people who best represent or personify the cultural values. Heroes provide organizational members with a concrete role model for behavior; (3) Rites and Rituals - The public perfomances that display and enact the values of the organization. Rituals are mundane, day-to-day activities that give direction to an oherwise chaotic world. Rites and Ritual provide expectations for members' behavior and reiterted the connection between corporate values and success; (4) Cultural Network - Consits of the informal communication network in the organization and is the primary carrier of cultral information between management and workers.

\section{Intercultural Conflict}

The organizational culture is influencing the people with unfamiliar habit, and in some cases it would be causes a conflict. Stella Ting-Toomey (1999, p.195) has stated that, "intercultural conflict revolves around diverse cultural approaches people bring with them in expressing their values, norms, rhythms, and style in managing conflict". The major characteristic of intercultural conflict are: (1) Conflict involves intercultural perceptions, (2) Conflict involves interactions, (3) Conflict involves interdependent,

(4) Conflict involves both self-interest and mutual-interest goals, and (5) Conflict involves the protection of intergroup images.

\section{Face Negotiation Theory}

As social beings, we have experiences so many kinds of feelings and different emotions depending on the situation. For instance, When you are proud of something that has been achieved succesfully, you will have a sense of pride feeling because what you have done for your community or organization. Moreover you receiving a praise and that praise happens to be in front of others. This is what we called prideful experience. On the contrary, there are a times for you to have experiences the feeling of embarrassing, shameful, humiliating or disgraceful when the others starting to provoke you, or even teasing you and you do care about what the others think, and it will causes the desire to save the 'face'.

'Face' is the concept how we want others to see us and treat us. Ting-Toomey (1998) in her research has stated that "Face refers to a claimed sense of favorable social self-worth that a person wants others to have of her or him" (p. 187). Due to the experiences of the kind of so many feeling in any uncertain social situation, it can be enhanced or threatened the 'face'. One of the situation that we need to save our 'face' is conflict management. It will also require active facework management. And culture involve in facework communication (Ting-Toomey, 1998). Face is about an individual assesment, and facework is about how we have to behave to protect or save the 'face' within sociacultural situation (Ting-Toomey, 2017).

Due to most cultures give their members a fairly strong emphasis on their 'face', most people aware that there is possibility to controlling 'face' and controlling outcome are interrelated (Donohue, 1992). Wilson and Putnam (as cited in Donohue, 1992) identity there are four different face needs: (1) 
Face maintenance - the desire to build one's image as competent and trustworthy person in order to void appearing weak or incapable; (2) Face saving - an effort to repairing a damaged image in response to look tough after someone else made you look weak as a defensive move; (3) Face attacking portraying the other as incompetent or untrustworthy peron in order to satisfy their face saving; (4) Face supporting - an action in order to bolster the other's image to fulfill their role obigations or protect role identities. Pruitt (as cited in Donohue, 1992) has stated that "loss of face communicates increased weakness" (p. 58), Donohue (1992) add that losing face itself can also result in other dire consequences for negotiators.Face negotiation theory has developed by Stella Ting-Toomey based on concept of 'face' that originally proposed by Brown and levinson in 1978. According toTing-Toomey (2001), face negotiation theory is the examination of the process based on what is factors of conflict interaction styles and conflict facework behaviors. In the other words, face negotiation theory has a role to investigates intercultural conflict styles.

In many kinds of conflict situations when one's face is being threatened, as a defensive move to avoid loss of face, face saving strategy are needed (Ting-Toomey, 2001). There are five styles of handling interpersonal conflict: (1) Dominating - one's own position or goal above the other persons to make decisions by dominating or controlling; (2) Avoiding - eluding the conflict topic, the conflict party, of the conflict situation altogether. In other words, staying away from the conflict: (3) Obliging - high concern for the other person's conflict interest above one's own conflict interest; (4) Compromising - a give and take concession in order to reach a mid-point agreement to come to a solutions; (5) Integrating - in order to solve the problem, it will involves high concern for one self and high concern for the others.

\section{THEORETICAL FRAMEWORK}

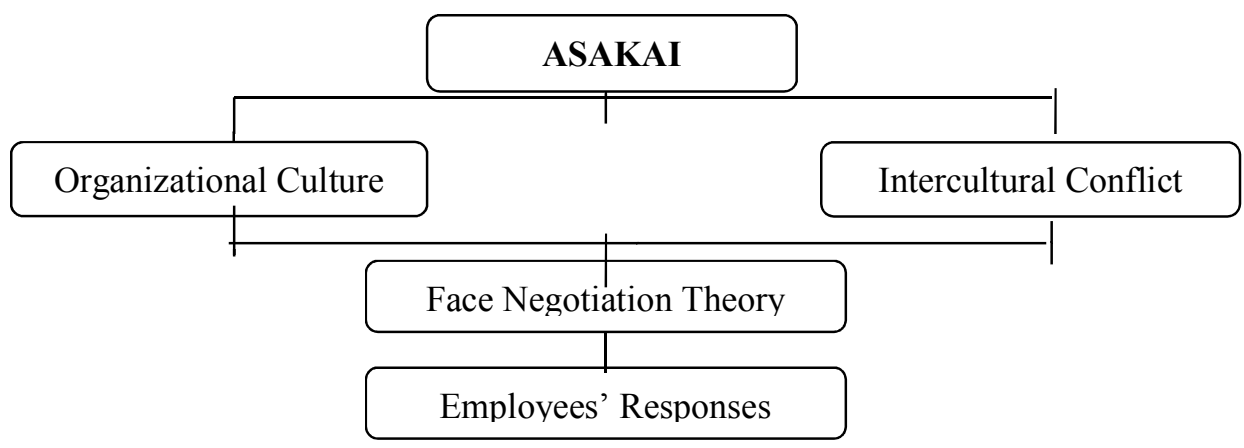

Figure 1. Theoretical Framework Asakai

The authordid research in consist of organizational culture and intercultural conflict to analyse how the local employees interact towards ASAKAI, and how are they handling the conflicts through face negotiation theory by Ting-Toomey (2001).

\section{METHOD}

Conducting this research, the author usedconstructivism paradigm. According to Denzin and Lincoln (2005), this paradigm oriented to the production of reconstructed understanding of the social world based on in-depth interview and observation. This paradigm allow us to learning environment encompasses activities an interpersonal interactions. Therefore the method for this research is using qualitative, typically phenomenological research. Data were collected by interviews and participants observation. 


\section{RESULT AND DISCUSSION}

According to the result analysis which based on interviews and observations, ASAKAI has a lot benefits for an organization. There is no activity without purpose. The purposes of ASAKAI are: (1) Evaluate and monitoring work activities. Through ASAKAI, the manager could monitoring the job loading and achievement of his/her team. Manager will evaluate the work performance. Moreover he/she even can control the division budget regarding over time issue. He/she will check whether overtime is needed or not with job loading that reported in ASAKAI; (2) Early problem detection. For the someone who still have less knowledge and experience, may be he/she cannot see what can the other see. Therefore, the employee are obliged to report whatever they did, and share whatever information that he/she has during ASAKAI. Moreover, there is no guarantee for everyone to have same point of view. It is possible to the other's participants of ASAKAI can detect a problem; (3) problem solving.

With different knowledges and experiences, the other will contribute to share his/her idea to help resolve the problem. But it doesn't mean ASAKAI is the media to find problem solving. Because It's depends on its problem, the knowledge, and the leadership quality of a manager. The researcher consider this one as the main purpose of ASAKAI. ASAKAI is involving two way communication between a management and its employees. Do reporting, and share information regularly as obligation till become a habit. Then, communication won't be an "expensive" thing within organization.

ASAKAI can be a media for the employee to have a chance to appeal his/her capability in order to enhanced the "face".All of the informants describes how they understand the concept and the purposes of ASAKAI. They do realize the benefits of ASAKAI itself. But at the same time, they experience a conflict. The conflict can be a reason to be a thing that threatened 'face'. In order to save the 'face', the employees has each style to handle the conflict itself. Since ASAKAI is not an original culture from Indonesia. At first author assumed that the local employees at TMMIN, are experincing intercutural conflict. But the truth revealed that the conflit caused by interpersonal conflict while perform ASAKAI every morning as regular activity.

Based on observations and interviews result, the following are the employees' response regarding ASAKAI activity. The employees confirmed that there is no intercultural conflit. The conflict occurred not because of cultural difference. Otherwise, the employees appreciate ASAKAI as a good and recommended activity to implement. ASAKAI is led by each Department Head with the different way. The way they do ASAKAI is following its Department Head's style. Different style is caused by the different character of every people as human being. Depends on its style, there are a kind of types that spur the employees to has intention avoiding ASAKAI (Avoding style).

There are two things that spur the employees to avoid ASAKAI, a manager and a conflict/debates. During reporting in ASAKAI, the employees need a feedback from the superiors to evaluate, share information, giving an idea or offer a helps (compromising style). When there are a thing that doesn't seems right for the employees, through debate or not, for some reasons, ocassionally they will ignore the instruction or guiding from their superiors during ASAKAI (dominating style). Rather than avoiding style, the employees seems to use integrating style to handling the conflict. To be coperative is not just about take something helpful for own concern. But also involve to contribute for the other's concern with purpose to give something helpful, and can place the other's concern high as its own. This is what Ting-toomey called as intergating style.

As interview resut 9 out of ten informants use this kind of style during ASAKAI.Circumstantially, through this style the employees can appeal their capability for face saving through output that they are reporting. Because, ASAKAI is about reporting output itself. Report how the employee doing their job, how they overcome a problem, and how they monitoring what is its responsbility. Then department head, or manager will evaluate that as assesment.

\section{REFERENCES}

Boer, R. F. (2018). Reputation Communication of Online Companies. Jurnal Komunikasi Ikatan Sarjana Komunikasi Indonesia, Vol 3(1): 36-44. http://www.jurnaliski.or.id/index.php/jkiski/article/view/147/pdf 
Denzin, N. K.., \& Lincoln, Y. S. (2005). Handbook of Qualitative Research. United States, America: C\&M Digitals

Donohue, W. A.., \& Kolt, R. (1992). Managing Interpersonal Conflict. Newbury Park, California: Sage Publications, Inc

Elashmawi, F., \& Harris, P. R. (1993). Multicultural Management: New Skills for Global Success. Houston, Tx: Gulf Publishing Companies

Gamble, T. K., \& Gamble, M. (2002). Harris, P. R. (1993). Communication Works. America: McGrawHill Companies

Modaff, D. P., DeWine, S., \& Butler, J. (2007). Organizational Communication. United States, America: Pearson Education

Schein, E. H. (2010). Organizational Culture and Leadership. San Fransisco: John Wiley \& Sons, Inc

Ting-Toomey, S., \& Kurogi, A. (1998). Facework Competence in Intercultural Conflict: An Updated Face-Negotiation Theory. International Journal of Intercultural Relations. 22 (2): $187-$ 225. doi:10.1016/s0147-1767(98)00004-2

Ting-Toomey, S. (1999). Communicating Across Culture. Newyork, London: The Guildford Press

Ting-Toomey, S., \& Oetzel, J. (2001). Managing Intercultural Conflict Effectively. Thousand Oaks, CA: Sage Publications, Inc

Ting-Toomey, S. (2017). Facework and Negotiation Theory. The International Encyclopedia of Intercultural Communication. United States, America: JohnWiley \& Sons, Inc. doi: 10.1002/9781118783665.ieicc0105 